\title{
Tagging huemul fawns (Hippocamelus bisulcus) at Torres del Paine National Park, Magallanes, Chile
}

\author{
Marcaje de cervatillos de Huemul (Hippocamelus bisulcus) \\ en el Parque Nacional Torres del Paine, Magallanes, Chile
}

Gladys Garay ${ }^{1}$, Oscar Guineo ${ }^{1}$ \& Isaac M. Ortega ${ }^{3}$

\begin{abstract}
There is no better approach in the study of social behavior of a species than recognizing individuals. For the similar looking animals as in the huemul (Hippocamelus bisulcus), were we could only differentiate between sexes and ages, marking became a critical need. In a long-term study of the huemul at Torres del Paine National Park, Chile, we wanted to recognize individuals as young as fawns, hence we adopted the technique learned from Franklin and Johnson (1994) to trap fawns during the birthing season. Teams looked-up for females suspected to have given birth to find the location of the hidden fawn. Once the fawn was located we proceeded to trap and mark it. In this way 16 fawns were trapped, measured, and ear-tagged. These animals were key for a better understanding of several aspects of the ecology of the huemul at that park.
\end{abstract}

\section{Key Words:}

Hippocamelus bisulcus, huemul fawns, marking, Chilean Patagonia.

\section{Resumen}

Una de las mejores formas para el estudio del comportamiento social de una especie, es el reconocimiento de los individuos. Para los animales de aspecto similar, como en el huemul (Hippocamelus bisulcus), donde sólo se puede diferenciar entre sexos y edades, el marcar individuos se convierte en una necesidad crítica. En un estudio a largo plazo del huemul realizado en el Parque Nacional Torres del Paine, Magallanes, Chile, el reconocimiento de individuos tan jóvenes como cervatillos resultó ser de suma importancia, por lo tanto, se adoptó la técnica aprendida de Franklin y Johnson (1994 ) para atrapar cervatillos durante la temporada de nacimientos. Equipos de investigadores buscaron y observaron hembras de las que se sospechaba haber parido, para así lograr la ubicación del cervatillo oculto. Una vez que se encontró el cervatillo se procedió a atraparlo, medirlo y marcarlo. De esta manera se atraparon, midieron y marcaron con auto-crotales a 16 cervatillos. Estos animales marcados fueron clave para una mejor comprensión de varios aspectos de la ecología del huemul en ese parque.

\section{Palabras Clave:}

Hippocamelus bisulcus, cervatillos de huemul, marcaje, Patagonia Chilena.

\section{INTRODUCTION}

To better understand the socio-ecology of a species, the marking of individuals to be later identified is highly desired. However, if this is not possible, it becomes necessary to use individual natural markings or special characteristics. There are several studies on deer species where fawns

\footnotetext{
1 Paraguaya 126, Punta Arenas, Chile. gladysenviaje@yahoo.com (GG); guineo.garay@gmail.com (OG).

2 Department of Natural Resources \& the Environment, University of Connecticut, Storrs, CT 06269, USA. $\checkmark$ morty.ortega@uconn.edu
} 
were captured for different purposes, such as mortality and survival (Pusateri Burroughs et al. 2006; Delguidice et al. 2006; Hiller et al. 2008, Lomas \& Bender, 2007; Pojar \& Bowden, 2004; Rhom et al. 2007; Vreeland et al. 2004), success in traps (Hiller et al. 2010), determining on how to find fawns (Ditchkoff et al. 2005), or used for food habit studies (Ortega et al.1990; Ortega et al. 1997). However, capturing and marking of fawns with the purpose of direct observation has not been documented.

In 1999 we began a study on a huemul (Hippocamelus bisulcus) population at Torres del Paine National Park (PNTP). Huemul fawns are spotless, but as many other deer species, fawns are hiders, lying down quietly out of sight, until the mother comes back to nurse it. Once the fawn grows into a juvenile (a year of age), there are practically no significant physical differences with the adults, although it is possible to notice a shorter neck in the juveniles. At six months of age, the male fawn begins to form small buttons that will develop into small antlers of one point, up to $6-8 \mathrm{~cm}$., at one and a half years of age. Males have small-bifurcated antlers with 2-points on each antler, up to $28-30 \mathrm{~cm}$. There are no antlers on the females. In our 10-year study, it became necessary to mark the individuals of the population of huemul at the PNTP. Since the huemul is an endangered species (IUCN 2010, declared in 1995) we limited ourselves to ask for permits to mark only huemul fawns. In part this decision was made based on the extensive experience of the researchers on the long-term research on guanaco (Lama guanicoe) in the same PNTP, where they captured and marked more than 30 neonatal guanacos, 15 - 20 minutes after birth (Garay, 1985), and assisted other students in later occasions (Franklin \& Johnson, 1994).

The main purpose of marking huemul fawns was to obtain information, through identifiable animals, on the organization and social relationships, distribution and movements of huemul and their families, and activity budgets. Marked animals could also provide basic information of the population size in the study area, dispersal of juveniles and adults. Moreover, through this procedure, huemul measurements could be obtained in a species that lacks this type of information.

\section{METHOD}

Study area

The huemul population considered for this procedure was in the Sector Lago Grey to the extreme west of Torres del Paine National Park $\left(51^{\circ} \mathrm{S}\right.$ and $\left.73^{\circ} \mathrm{W}\right)$, an area that borders the Southern Ice Field. Due to the vastness of the area $\left(375 \mathrm{~km}^{2}\right)$ and the scattered distribution of huemul given its small population (about 60 animals, Guineo et al. 2000), we chose groups that were close to the last point of vehicular access in the area of Grey Lake's Park Ranger Station. It covered approximately $23 \mathrm{~km}^{2}$ including four subsectors: Pochongo, Margaritas, Cañadon - Mirador, and Aguila - Huemules (Fig. 1).

This study site is a very challenging area in a very uneven topography, due the great orogenic activity and glacio-fluvial action, and the strong rocky slopes and moraine presence. The study site is located on the Trans-Oceanic and the Andean ecological region (DiCastri, 1968) with rainfall of 800 to $850 \mathrm{~mm}$ per year, within the range of the Eastern Pre-Andean features with Magellan forest vegetation of deciduous and mixed (Pisano, 1974). The periglacial location and colonizing human influence for nearly 100 years, is manifested in large forest fires that were used to "open grazing areas," which generated the presence of bush patches of various sizes within the open wooded areas.

The dominant tree species in this area are beech (Nothofagus pumilio) and coigüe ( $N$. betuloides), with some nirre ( $N$. antarctica) and low-lying areas stunted at higher levels of the mountain. The dense patches of mesophytes shrubs include ciruelillo (Embothrium coccineum), leñadura (Maitenus magellanica), calafate (Berberis buxifolia), bacaris (Baccharis magellanica), chaura (Gaultheria mucronata), and murtilla (Empetrum rubrum). The lack of grazer species in the area has allowed grasses to remain high in most of the area. Some of the most abundant grasses and herbs include orchard grass (Holcus lanatus), honey grass (Dactylis glomerata), coiron (Festuca spp.), dandelion (Taraxacum officinalis), clover (Trifolium repens), site vends (Plantago 


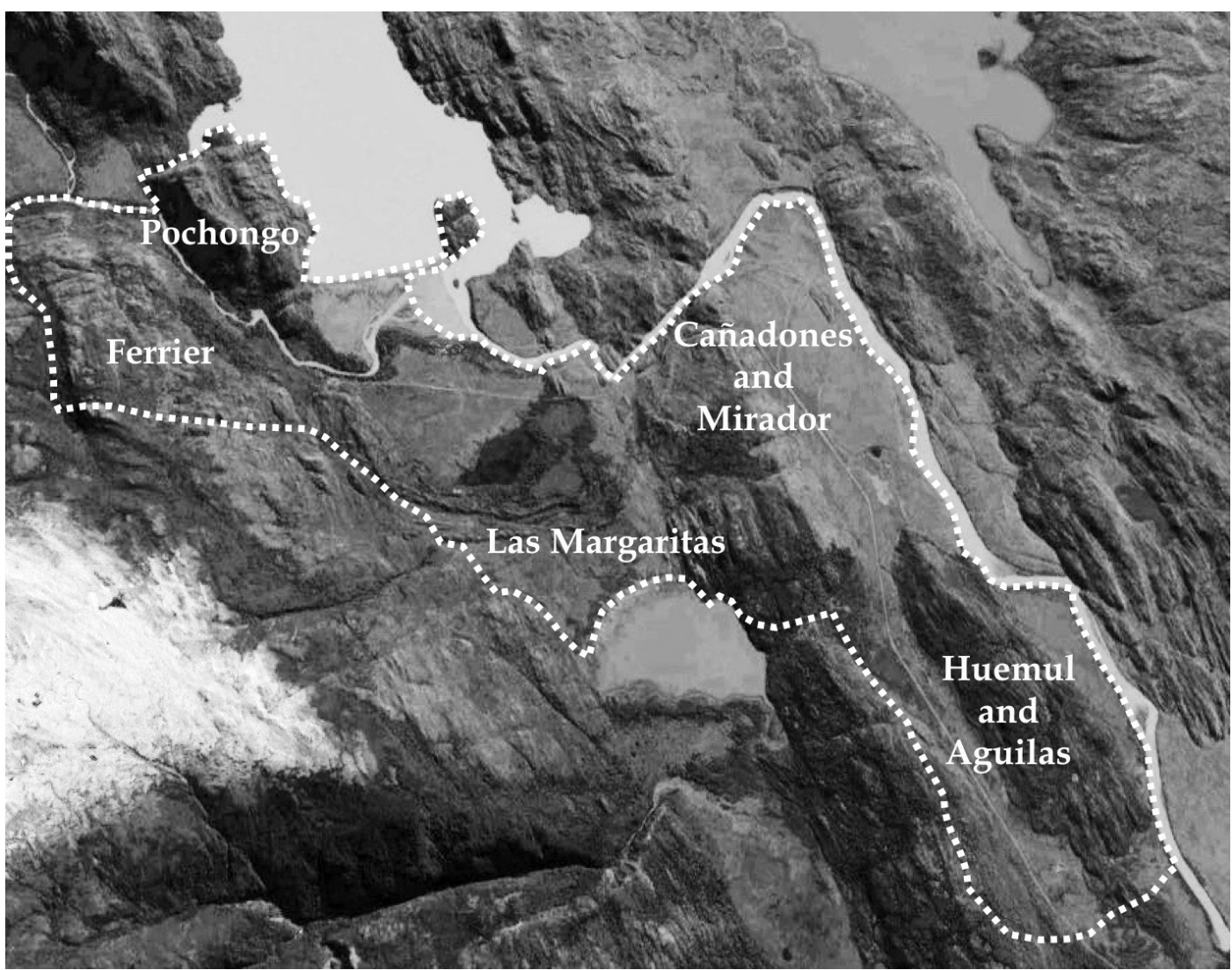

Fig. 1. Study area of the huemul population at Torres del Paine National Park, Magallanes, Chile, 2002 - 2008. (Source: Google Earth 2010).

lanceolata), arvejilla (Lathyrus magellanicus) and wild sweet peas (L. nervosus).

\section{Permits}

For each tagging period, permits were requested to CONAF (Corporación Nacional Forestal) and SAG (Servicio Agrícola y Ganadero). The permits per year included 2002 Resolution 11; 2003 Resolution 3315; 2004 Resolution 3219; 2005 Resolution 5112; 2006 Resolution 4407; 2007 Resolution 4188; and 2008 Resolution 4883.

\section{Tagging Procedures}

Fawn tagging was done between late October and mid November, from 2002 to 2008 which corresponds to the birthing season of huemul in this region. Three people were needed for the tagging of the fawns.

To tag the fawns we used blue and yellow ear tags $(3 \times 2 \mathrm{~cm})$, ear tag pliers, measuring tape, a scale and a belt to weight the fawn, cloth to cover the eyes, antibiotic spray to put in the area of the ear affected by the insertion of the ear tag. Data were recorded in data sheets prepared for the field procedure. Pictures and movies were shot during the process.

Adult pregnant females usually moved away from the group during the birthing period and at least for the first two weeks after the fawn were born. We used this behavior to help us in locating fawns. First, we observed females with this type of behavior; once the female was located, we observed the female until she moved to lactate the fawn. If no lactation was observed, but the female persisted in the site, then an exhaustive search was done in the area within a radius of $200 \mathrm{~m}$. Usually the female did not 
show apprehension and continued eating.

Once the fawn was located and did not move, a member of our team approached it, and held it down to the ground. The second member proceeded to tag it on both ears, with the exception of 2006 to 2008 where only one eartag was placed. Standard body measurements were done, including length of tail, ear, head, hind and fore leg, and total length, circumference of the head, neck and chest. We also measured length and width of hoof. Holding it with a belt around the chest and using a spring scale we obtained the weight of the fawn. The third person was in charge of taking pictures and collecting any data obtained. Other data collected at the time included GPS location, weather conditions, topography, wind cover, shade cover, and habitat type. Also, information about any other huemul in the area was recorded. Once the tagging and measuring was done, the fawn was left in the same location it was originally found, remaining in place until the female approached. The whole procedure lasted between 5 and $7 \mathrm{~min}$.

\section{RESULTS}

This capture technique allowed us to mark 16 huemul fawns: 10 females and 6 males. The earliest tagging was done as early October 28 and the latest on November 24, although we searched

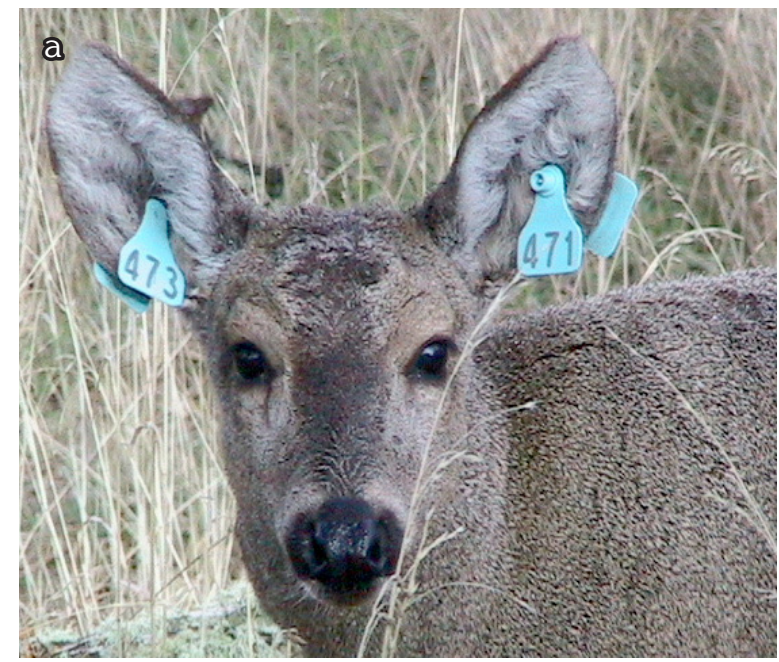

Fig. 2. Huemul number 471-473 marked in 2003 at Torres del Paine National Park, (a) at three month of age, and (b) at thirteen years old, sighted last in October 2016. for fawns before and after those dates.

The capture technique is very effective although it requires being very patient and able to spend a long time in the huemul range. There is no need for drugs and the animals are unharmed at the time of released. The does remained nearby without paying much attention to the procedure. Only on two occasions females were alarmed by a short cry from the fawn, but most times, if the fawn was not making any noises, the doe remained very calm, although attentive to our presence. After the tagging was done and we moved away from the scene, the doe approached her young, whom usually started to nurse (see Fig 2 , a marked female at three-month and at thirteen years old).

The tagging of these animals allowed us to establish some family relationships and recognition of the individuals that remained in the study site (Table 1). We found no significant differences $(p<0.001)$ of the body measurements between the sexes (Table 2). The average weight of fawns was $6.84 \mathrm{~kg}$ (SD 1.11), average total length was 73.71 (SD 4.53), height was 42.39 (SD 3.85), chest circumference $55.75 \mathrm{~cm}$ (SD 12.08), and ear length was $9.93 \mathrm{~cm}$ (SD 1.55) (Table 2).

\section{DISCUSSION AND CONCLUSIONS}

The capture and tagging of the 16 fawns in

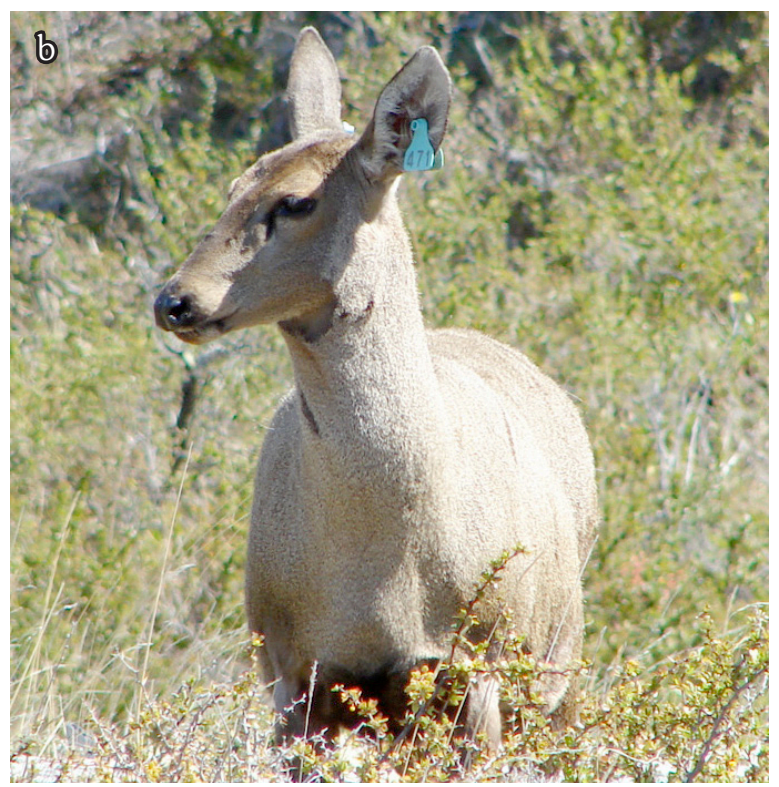


Table 1. List of huemul tagged between 2002 and 2008, its relation to others, and last sighting from the study site, Torres del Paine National Park, Chile. (Areas: Ma: Margaritas;

Po: Pochongo; Hu: Huemules; Ca: Cañon; Fe: Ferrier; see further explanation in the text)

\begin{tabular}{|c|c|c|c|c|c|}
\hline $\begin{array}{l}\text { Year of } \\
\text { tagging }\end{array}$ & Area & $\begin{array}{l}\text { Fawn } \\
\text { number }\end{array}$ & Sex & $\begin{array}{l}\text { Known relationship to other } \\
\text { huemul in the area }\end{array}$ & Last sighting \\
\hline 2002 & $\mathrm{Ma}$ & 763 & M & & Left the area Jun 2003 \\
\hline 2002 & Po & 798 & $\mathrm{~F}$ & & $\begin{array}{l}\text { Left the area Oct } 2003 \text {, sighted in August } \\
2015 \text { Pingo sector with a male. At the time } \\
\text { she was } 12 \text { years and } 10 \text { month old }\end{array}$ \\
\hline 2003 & Po & $459-461$ & $\mathrm{~F}$ & Sister of 798 & Moved to Ca Jul 2007 \\
\hline 2003 & $\mathrm{Ma}$ & $471-473$ & $\mathrm{~F}$ & Sister of 763 & Oct 2016 , at the time 13 years old \\
\hline 2003 & $\mathrm{Hu}$ & $465-46$ & $\mathrm{~F}$ & & In Hu Nov 2009 \\
\hline 2004 & $\mathrm{Ma}$ & $58-6$ & $\mathrm{~F}$ & & Not from the area. Ferrier mountain Apr 2005 \\
\hline 2004 & $\mathrm{Ca}$ & $46-47$ & M & & Puma predated Dec 2004 \\
\hline 2005 & $\mathrm{Ma}$ & $51-53$ & M & Son of $471-473$ & Puma predated Dec 2005-Jan 2006 \\
\hline 2005 & $\mathrm{Ma}$ & $55-57$ & $\mathrm{~F}$ & Sister of $471-473$ & Left the area Nov 2006 \\
\hline 2005 & $\mathrm{Ca}$ & $52-54$ & M & & Not from the area. Feb 2006 \\
\hline 2006 & $\mathrm{Ma}$ & 462 & $\mathrm{~F}$ & Daughter of $471-473$ & Moved to Po Nov 2009 \\
\hline 2006 & $\mathrm{Fe}$ & 67 & M & & Not controlled since it was located in Ferrier \\
\hline 2006 & $\mathrm{Hu}$ & 64 & $\mathrm{~F}$ & Daughter of $465-46$ & Not seen again, just her mother \\
\hline 2006 & $\mathrm{Ca}$ & 68 & M & & $\begin{array}{l}\text { Not from the area. Not seen again, neither his } \\
\text { mother }\end{array}$ \\
\hline 2007 & $\mathrm{Ma}$ & 70 & $\mathrm{~F}$ & & $\begin{array}{l}\text { Not from the area. Not seen again, neither her } \\
\text { mother }\end{array}$ \\
\hline 2008 & $\mathrm{Ma}$ & 66 & $\mathrm{~F}$ & Daughter of $471-473$ & In Ma Nov 2009 \\
\hline
\end{tabular}

Table 2. Huemul tagged morphometric measurements (mean and standard deviation in parenthesis), Torres del Paine National Park, Chile, 2002-2008.

\begin{tabular}{lccccc}
\hline Sex & Weight $(\mathrm{kg})$ & Total Length $(\mathrm{cm})$ & Height $(\mathrm{cm})$ & Chest Circumference $(\mathrm{cm})$ & Ear Length $(\mathrm{cm})$ \\
\hline Females (9) & $6.78(1.07)$ & $72.89(4.20)$ & $42.83(4.62)$ & $55.61(13.59)$ & $9.30(1.36)$ \\
Males (5) & $6.96(1.30)$ & $75.20(5.22)$ & $41.60(2.07)$ & $56.00(13.66)$ & $11.2(1.15)$ \\
\hline
\end{tabular}

a period of seven years was a success, considering that this was done with only one three-person team, although in 2006 we had two groups of 3 people each, which help in successfully capture four fawns that season. Having more teams in the area during the birthing season of the huemul, could have helped to increase the number of animals caught without producing too much disturbance to its population. Researchers willing to adopt this capturing technique must spend several weeks before the birthing season observing the behavior of the animals to establish movement patterns and location of family members, especially the females.
Once the patterns are established, it becomes easier to locate the females that have fawns, consequently revealing the locations of fawns for the capture.

This is a technique that requires a minimal intervention on the fawn, without overly stressing the mother, whom usually quietly observed the team at work and continued feeding. It is worth mentioning that one of the tagged females had three fawns, which were also marked, with no evidence of agitation by her during the capture and tagging of her own fawns.

Since drugs are not used in this method and the procedure is fairly fast, the marked animals 
suffered the least intrusion and stress was minimal. No pattern of increased mortality was detected by predators because of handling of the fawn or by the presence of the large ear tags. We highly recommend this technique for endangered species ungulates to avoid unnecessary mortality of populations already weakened by the stress put on them by humans.

\section{ACKNOWLEDGEMENTS}

We would like to thank many people that helped in the tagging. We especially thank the local park ranger of the Sector Lago Grey, Mr. Fredy Barrientos, who has dedicated a large portion of his work to study and protect the huemul population in the area. We also would like to thank many volunteers involved, including C. Carmona, B. López, J. Sotomayor, C. Torres and some of the field guides from the Hosteria Lago Grey and Hosteria las Torres. We also would like to thank the logistic support from the administradores y gerentes: J. Salas, J. Gutiérrez, D. Seron de Hosteria Lago Grey, y L. Kusanovic, V. Méndez, C. Soto, C. Morales del Hotel Las Torres, and the Patagonia-UConn Expeditions.

\section{LITERATURE CITED}

Delguidice, G. D., Fieberg, J., Riggs, M. R., Powell, M. C., \& Pan, W. (2006). A longterm age-specific survival analysis of female white-tailed deer deer. Journal of Wildlife Management, 70, 1556-1558.

Di Castri. F. (1968). Equisse ecologique de Chili. Biol. De l' Amerique Austral. Paris, 4. Centre Nat. De Rech. Scient.

Ditchkoff, S. S., Ranglin, J. B., Smith, J. M., \& Collier, B. A. (2005). From the field: capture of white-tailed deer fawns using thermal imaging technology. Wildlife Society Bulletin, 33,1164-1168.

Franklin, W. L., \& Johnson, W. E. (1994). Hand capture of newborn open-habitat ungulates: the South American guanaco. Wildlife Society Bulletin, 22, 253-259.

Garay. G. (1985). Desarrollo del comportamiento social infantil del guanaco (Lama guanicoe) en Torres del Paine. Tesis de Grado. Pontificia Universidad Católica de Chile.
Garay, G., Guineo, O., \& Ortega, I. M. (2000). Informe prospección de huemules (Hippocamelus bisulcus) sector Lago Grey, Parque Nacional Torres del Paine. Magallanes - Chile. Proyecto UConn Patagonia.

Hiller, T. L., Pusateri Burroughs, J., Campa III, H., Cosgrove, M. K., Rudolph, B. A., \& Tyre, A. J. (2010). Sex-age selectivity and correlates for winter-trapped white-tailed deer. Journal of Wildlife Management, 74, 564-572.

Hiller, T. L., Campa III, H., \& Winterstein, S. R. (2008). Survival and space use of fawn white-tailed deer in Southern Michigan. American Midland Naturalist, 159, 403412.

IUCN (2010). IUCN Red List of Threatened Species. Version 2010.1. www.iucnredlist. org

Lomas, L. A., \& Bender, L. C. (2007). Survival and cause-specific mortality of neonates deer fawns, north-central New Mexico. Journal of Wildlife Management, 71, 884-894.

Ortega, I. M., Perry, L. D., Drawe, D. L., \& Bryant, F. C. (1990). Observations on obtaining white-tailed deer fawns for experimental purposes. Texas Journal of Science, 42, 69-72

Ortega, I. M., Soltero-Gardea, S., Bryant, F. C., \& Drawe, D. L. (1997). Evaluating grazing strategies for cattle: Deer forage dynamics. Journal of Range Management, 50, 615621.

Pisano, E. (1974). Estudio ecológico de la región continental sur del área andino-patagónica. II Contribución a la fitogeografía de la zona del Parque Nacional Torres del Paine. Anales del Instituto de la Patagonia, 1-2, 59-103.

Pojar, T. M., \& Bowden, D. C. (2004). Neonatal mule deer fawn survival in westcentral Colorado. Journal of Wildlife Management, 68, 550-560.

Pusateri Burroughs, J., Campa III, H., Winterstein, S. R., Rudolph, B. A., \& Moritz, W. E. (2006). Cause-specific mortality and survival of white-tailed deer fawns in southwestern lower Michigan. Journal of Wildlife 
Management, 70, 743-751.

Rohm, J. H., Nielsen, C. K., \& Woolf, A. (2007). Survival of white-tailed deer fawns in southern Illinois. Journal of Wildlife Management, 71, 851-860.
Vreeland, J. K., Diefenbach, D. R., \& Wallingford, B. D. (2004). Survival rates, mortality causes, and habitats of Pennsylvania whitetailed deer fawns. Wildlife Society Bulletin, $32,542-553$. 
